\title{
ESTIMATION OF FLOOD RISK MANAGEMENT IN 17TH CENTURY ON OKAYAMA ALLUVIAL PLAIN, JAPAN, BY NUMERICAL FLOW SIMULATION
}

\author{
TADAHARU ISHIKAWA ${ }^{1} \&$ RYOSUKE AKOH ${ }^{2}$ \\ ${ }^{1}$ Dept. of Civil and Environmental Engineering, Hosei University, Japan. \\ ${ }^{2}$ Graduate School of Environmental and Life Science, Okayama University, Japan.
}

\begin{abstract}
In this study, the hydraulic function of the Hyakken-gawa Floodway, which was constructed in the 17 th century to reduce the flood risk to Okayama Castle City, was evaluated by numerical flow simulation. The calculation conditions were determined by referring to the records about the floodway in old documents as well as from the numerical data based on the present conditions. The alluvial plain topography used for the inundation calculation was obtained from recent GIS data. The computation results showed that the flood control function of the floodway was composed of two stages: (1) Just before inundation occurred in the castle city, river water flowed into the floodway by collapsing the earthen dike located at the floodway head; this limited the increase in the river flow rate in the city area. (2) Just before the floodway capacity was exhausted, the backwater generated by the transverse masonry dikes in the floodway induced inundation to the paddy field region, which was on the side opposite to the castle city; this reduced the flood damage in the city area. The results also suggested that the civil engineers in the 17th century, who had neither the knowledge of modern hydraulics (including the concept of river flow rates) nor the advantage of using machinery for construction, presumably developed flood risk management strategies by combining the measures possible in those days. Finally, the results indicate that the floodway design used to distinguish the paddy fields from the urban areas for flood acceptance can be utilized for risk management against extraordinary floods even in present times.

Keywords: 17th century, distinction of land use, floodway function, historic flood risk management, numerical flow simulation, transfer of flood risk.
\end{abstract}

\section{INTRODUCTION}

In the 17th century, a long floodway named Hyakken-gawa was constructed to reduce the flood risk from the Asahi River to Okayama Castle City located on an alluvial plain in the mid-west part of Japan. Because the civil engineers of the day did not have the knowledge of modern hydraulics or the advantage of using large construction machinery, the planning and design was entirely empirical, and the dimensions of embankments were limited because only manual labor was employed. However, the main structure of the floodway survived until the end of the 19th century without much modification. Although the banks and the structures providing flow divergence were enlarged and reinforced with concrete in the 20th century, the design concept and framework of the system are still valid.

Taniguchi et al. [1] summarized the background and process of constructing Hyakken-gawa based on old documents and drawings from the standpoint of historical science. According to them, because of the lack of knowledge about velocity vectors, the engineers of the day wrongly believed that the flow divergence was controlled by the ratio of the cross-sectional 


\section{Flood Risk Management and Response}

areas of the channel. Imamoto et al. [2] assumed the flood hydrograph for the floodway design by comparing the flooding records for the 17 th and 18th centuries with recent hydrological data and performed a hydraulic model test to investigate the flow diverging from the Asahi River to the floodway. However, the reliability of their experimental result was questionable because the river reach of the model was too short [3]. Therefore, the actual hydraulic function of the system for the reduction of flood risk in the castle city has not been fully understood yet.

In this study, a series of numerical flow simulations were performed to investigate the capacity of the floodway, the function of structures at the floodway head, the reduction of flood risk in the castle city, and the manner in which the civil engineers of the day managed floods larger than the channel capacity. A two dimensional shallow water equation formulated on an unstructured triangular mesh system was adopted for the numerical simulation. The calculation conditions were assumed by referring to the description and data on floods available in the literature $[1,2]$ as well as recent hydrological and surveying data. The simulation results were collected and arranged to estimate the flood risk management in the 17th century when the construction scale was limited and to discuss the possibility of applying these results to reduce the risk of floods exceeding the channel capacity, which may happen occasionally even in present times.

\section{STUDY SITE}

Figure 1 shows the location, an old map drawn in the late 17th century, and a recent aerial photograph of the study site. The white rectangle in Fig. 1c represents the area shown in Fig. 1b. The castle city was developed on the west side of the Asahi River, considering the bending part of the channel as a moat of the castle. However, because flooding often occurred at the bending, the local government planned the development of a floodway in the farmland on the east side of the river, which had wide paddy fields on low land and villages distributed at relatively high spots. The floodway was enclosed by banks located on the original ground, and these banks had some openings for irrigation channels and roads. During flooding, wooden blocks were inserted into the slots on the side face of the openings to close them.

(a) Location

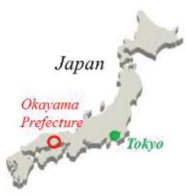

(b) $17^{\text {th }}$ century map

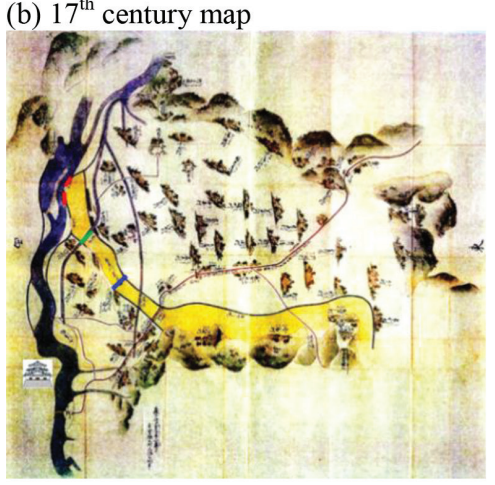

(c) Present map

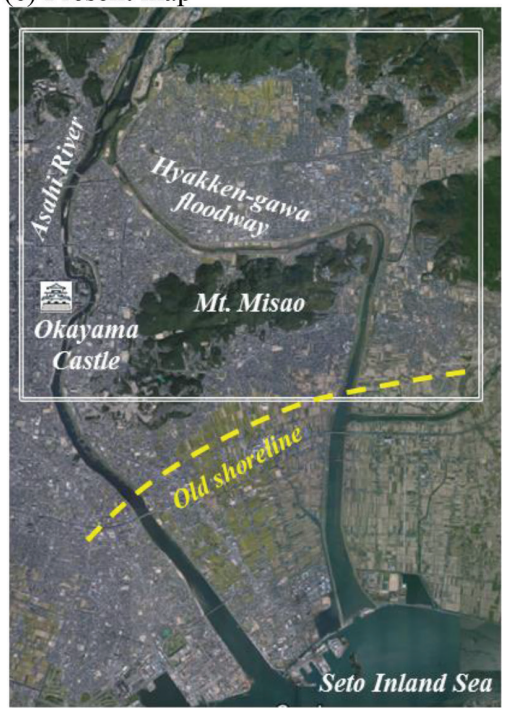

Figure 1: Study site: (a) location, (b) 17th century map, and (c) present map. 
At present, the urban area extends to the east side of Hyakken-gawa. The floodway has a composite cross section to ensure large flow capacity; the low water channel is always filled with water, but the level of the high water channel is almost equal to the level of the outside ground, as was the case in the 17th century. The course and width of the river and floodway have not changed much since the 17th century. However, the shoreline has moved from the yellow broken line to the present position because of reclamation in the Seto Inland Sea.

The three thick colored lines marked on the floodway in Fig. 1b show the locations of transverse dikes that control the flow into the floodway. The first dike (red) was made of earth, and it was lower than the neighboring banks; hence, it was broken in a short time when the river water overtopped it. The main body of the second dike (green) was masonry, but it had a 30-cm-thick cap made of earth. The third dike was entirely masonry. The approximate heights of the first and second dikes were recorded in the early 20th century [4], but that of the third dike is not known because it was destroyed by a large flood in the 19th century. In this study, the height of the third dike was assumed to be the same as that of the second dike.

\section{NUMERICAL MODEL}

A set of shallow water equations was adopted for the numerical simulation model.

$$
\begin{gathered}
\frac{\partial h}{\partial t}+\frac{\partial(U h)}{\partial x}+\frac{\partial(V h)}{\partial y}=0 \\
\frac{\partial(U h)}{\partial t}+\frac{\partial(U U h)}{\partial x}+\frac{\partial(U V h)}{\partial y} \\
=-g h \frac{\partial H}{\partial x}+\frac{\partial\left(h \tau_{U U}\right)}{\partial x}+\frac{\partial\left(h \tau_{U V}\right)}{\partial y}-\frac{\tau_{0}}{\rho} \frac{U}{\sqrt{U^{2}+V^{2}}} \\
\frac{\partial(V h)}{\partial t}+\frac{\partial(U V h)}{\partial x}+\frac{\partial(V V h)}{\partial y} \\
=-g h \frac{\partial H}{\partial x}+\frac{\partial\left(h \tau_{U V}\right)}{\partial x}+\frac{\partial\left(h \tau_{V V}\right)}{\partial y}-\frac{\tau_{0}}{\rho} \frac{V}{\sqrt{U^{2}+V^{2}}}
\end{gathered}
$$

where $(U, V)$ are the velocity components in $(x, y)$ coordinates, $h$ is the water depth, $H$ is the water surface level ( $=h+$ ground level), $\rho$ is the water density, and $g$ is the gravitational acceleration. $\tau_{0}$ is the bed friction force, and $\tau_{U U}, \tau_{U V}$ and $\tau_{V V}$ are the horizontal shear stresses, which are expressed by the following equations:

$$
\begin{gathered}
\tau_{0}=\rho U_{f}^{2}=n^{2} \frac{\rho g\left(U^{2}+V^{2}\right)}{h^{1 / 3}} \\
\tau_{U U}=2 \varepsilon \frac{\partial U}{\partial x}-\frac{2}{3} k \quad \tau_{U V}=\varepsilon \frac{\partial U}{\partial y}+\varepsilon \frac{\partial V}{\partial x} \quad \tau_{V V}=2 \varepsilon \frac{\partial V}{\partial y}-\frac{2}{3} k \\
\varepsilon=\frac{1}{6} k U_{f} h \quad k=2.07 U_{f}^{2}
\end{gathered}
$$




\section{Flood Risk Management and Response}

where $U_{f}$ is the friction velocity, $n$ is Manning's roughness coefficient, $\varepsilon$ is the vertically averaged eddy viscosity, $k$ is the turbulent kinetic energy, and $\kappa$ is the Karman constant (0.41).

The differential equations were converted to difference equations by the finite volume method on the unstructured triangular mesh system. The equation forms and solving process are described in a previous paper [4]. The triangular meshes were generated from the bank lines and the outline of the inundation area using the software ANSYS.

The flow rate over the dikes and banks was calculated using the following formula [5]:

$$
q= \begin{cases}0.35 h_{1} \sqrt{2 g h_{1}} & \text { if } h_{2} / \mathrm{h}_{1} \leq 2 / 3 \\ 0.91 h_{2} \sqrt{2 g\left(h_{1}-h_{2}\right)} & \text { otherwise }\end{cases}
$$

where $q$ is the flow rate over the unit length, and $h_{1}$ and $h_{2}$ are the water depths on the upstream and downstream sides, respectively. The height reduction rate of the earthen first dike and the earthen cap of the second dike was assumed to be $0.36 \mathrm{~m} / \mathrm{min}$ based on an existing study [6].

\section{CALCULATION CONDITION}

\subsection{Topography}

A report on river improvement works since the 19th century [7] suggests that the bank lines of the Asahi River and Hyakken-gawa in the 17th century were almost the same as the present ones. However, because no information was available about the channel bed elevation of Asahi River in the 17th century, we adopted the recent surveying data of channel cross sections for calculation. On the other hand, the channel bed elevation of Hyakken-gawa was considered to be almost the same as that of the present high water channel, and the channel cross sections were obtained by removing the data for the low water channel from the recent surveying data. Manning's roughness was assumed to be 0.28 and 0.35 for the Asahi River and Hyakken-gawa Floodway, respectively, based on existing studies $[8,9]$.

According to the modern policy for flood risk management in Japan, the safety level should be kept equal for each river watershed, except for special cases such as the inside of flood-retarding basins. In the 17th century, on the other hand, uneven treatment depending on the land use was common because of poor flood control facilities. Actually, the Hyakken-gawa Floodway itself was expected to transfer the flood risk from the castle city to the farming area on the east. Therefore, we supposed that the east bank of Hyakken-gawa was a little lower than the west bank. The height of the east bank from the high water channel bed was assumed to be $3 \mathrm{~m}$ by measuring the remaining fragments of old banks (Picture. 1), whereas the overflow from the west bank was not considered. The topography of the alluvial plain was obtained from the GIS data (2001), which is shown in Fig. 2 along with the boundary for the numerical flow simulation. The total number of grid points for the calculation was 106,252.

\subsection{Hydraulic condition}

The highest water level at each big flood event since the 17th century was measured at the Kyobashi Station in the castle, and the critical water level for inundation was 4.5 T.P.m (T.P.m; standard unit of measurement for the elevation above the average sea level in Japan) [1]. A 


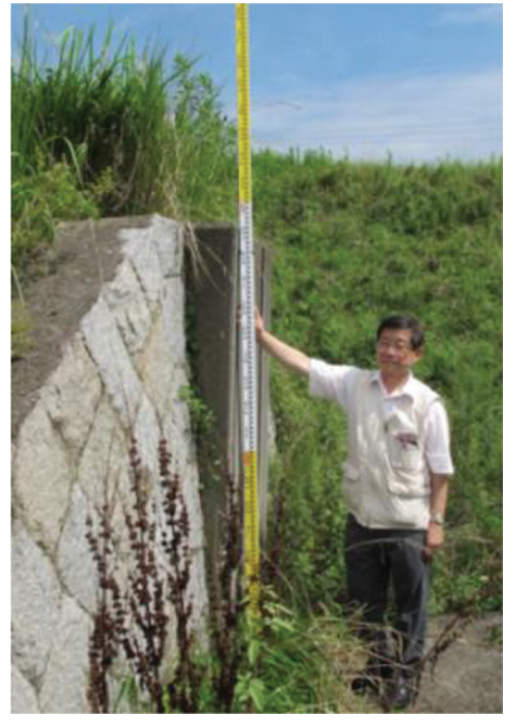

Picture 1: Old bank

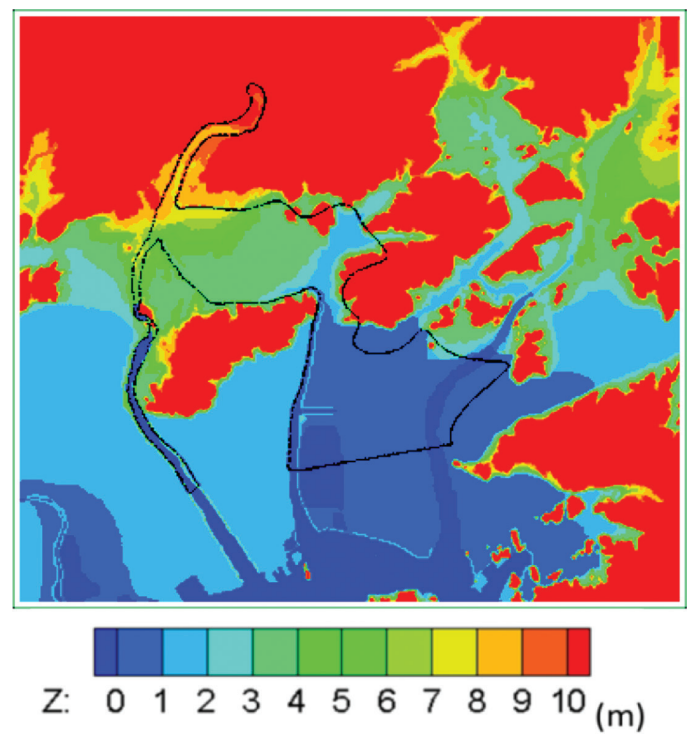

Figure 2: Topography of alluvial plain.

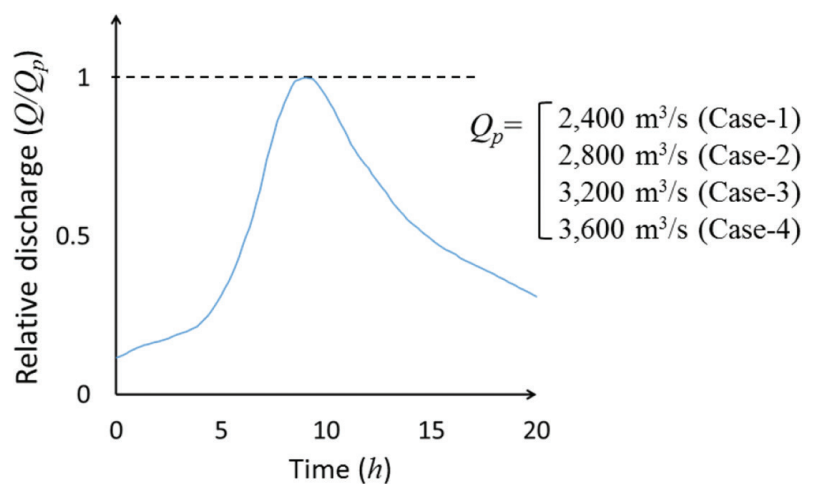

Figure 3: Flood hydrograph used for numerical simulation.

preliminary test using one-dimensional flow calculation with $n=0.028$ for the Asahi River showed that the flow divergence to Hyakken-gawa started before the water level reached the critical line, as was mentioned in the old document; the preliminary test also showed that the flood discharge at the critical water level was $2,000 \mathrm{~m}^{3} / \mathrm{s}$ [3]. Therefore, flood events larger than this level were considered in this study. A series of assumed flood hydrographs were obtained by changing the scale of the hydrograph that is adopted by present flood prevention works (Fig. 3).

The downstream ends considered in the calculation were the river mouths at the old shoreline shown in Fig. 1c, where the water level was assumed to be 0.25 T.P.m, which is the average tidal level recorded at the nearest tidal station. 
6 Flood Risk Management and Response

\section{RESULTS AND DISCUSSION}

\subsection{Velocity field at the floodway head}

Because of space constraints in this paper, the results from only Case-3 $\left(Q_{p}=3,200 \mathrm{~m}^{3} / \mathrm{s}\right)$ are illustrated in detail to explain the typical flow characteristics in the floodway system. Figure 4a and $\mathrm{b}$ show the velocity field near the floodway head (arrows) and the ground elevation (background colors) at $Q=2,600$ and $3,200 \mathrm{~m}^{3} / \mathrm{s}$, respectively. The first dike was already broken by the flow intruding into the floodway (two openings along the separating bank). The flow vectors are changed from the direction of the Asahi River to that of the floodway by the second dike. A bank overflow occurs between the second and third dikes at $Q=3,200 \mathrm{~m}^{3} / \mathrm{s}$. Figure 5 shows the longitudinal profiles of the water surface near the floodway head at the two $Q$ values. The second dike induces a hydraulic jump, reducing the energy of the flow along the downstream channel of the floodway. The third dike induces a side overflow in the backwater, but the reach of the overflow is confined to the section between the two dikes.

\subsection{Inundation on the alluvial plain}

Figure 6a shows the hydrograph for the floodway (red line) along with the flood hydrograph for the region upstream of the Asahi River (blue line) in Case-3 $\left(Q_{p}=3,200 \mathrm{~m}^{3} / \mathrm{s}\right)$. Flow

(a) $Q=2,600 \mathrm{~m}^{3} / \mathrm{s}($ Case- 3$)$

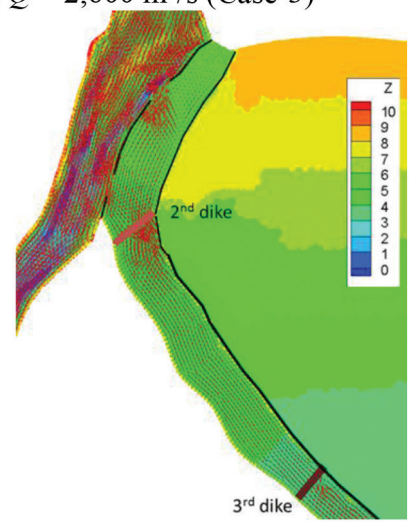

(b) $Q=3,200 \mathrm{~m}^{3} / \mathrm{s}$ (Case-3)

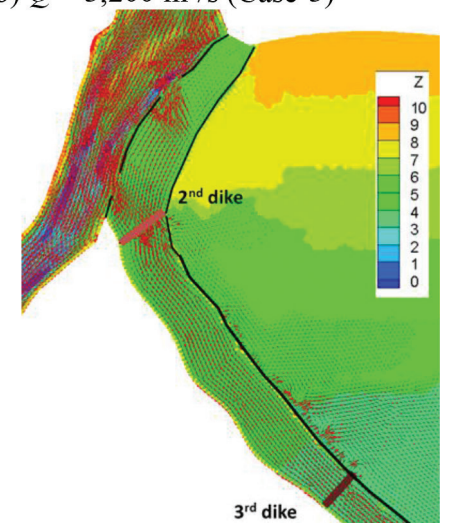

Figure 4: Velocity field near floodway head (Case-3, $Q_{p}=3,200 \mathrm{~m}^{3} / \mathrm{s}$ ).

(a) $Q=2,600 \mathrm{~m}^{3} / \mathrm{s}($ Case- 3$)$

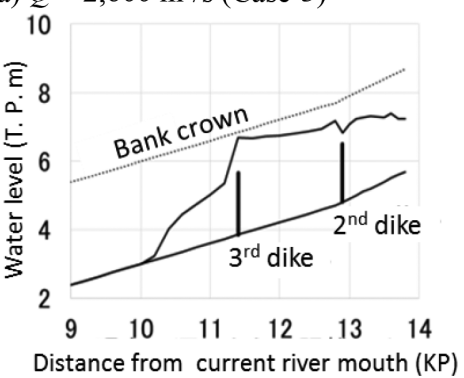

(b) $Q=3,200 \mathrm{~m}^{3} / \mathrm{s}($ Case-3)

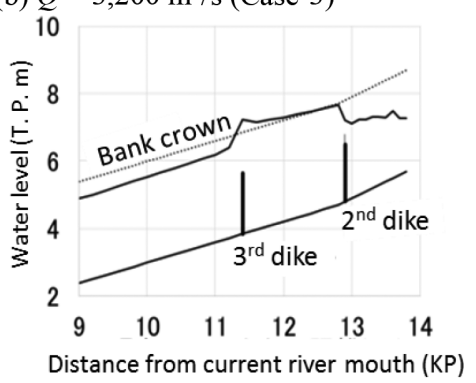

Figure 5: Longitudinal water surface profiles (Case- $\left.3, Q_{p}=3,200 \mathrm{~m}^{3} / \mathrm{s}\right)$. 
divergence started when the river discharge exceeded $2,000 \mathrm{~m}^{3} / \mathrm{s}$, and a maximum divergence of $800 \mathrm{~m}^{3} / \mathrm{s}$ was attained at the flood peak. Bank overflow started when the floodway discharge reached $500 \mathrm{~m}^{3} / \mathrm{s}$. Figure $6 \mathrm{~b}$ and $\mathrm{c}$ show the inundation progress on the alluvial plain for the two stages shown in Fig. 6a and d shows the maximum inundation depth during the flood event. The flood water flowed through the section between the two dikes along the channel bank following the ground elevation. The maximum water depth was less than $40 \mathrm{~cm}$ except in the area close to the third dike, which is acceptable for a paddy field if the inundation does not last very long.

It should be noted that a famous big shrine is located near the floodway head, which was built by the feudal lord of this district before the construction of Hyakken-gawa. The governing classes offered worship at the shrine for a long time. Although the shrine was located on the alluvial plain, it was not hit by the flood water discharged between the two dikes because of the mild ground slope from the north to the south.

\subsection{Reduction of flood risk in the castle city}

Figure 7 shows the calculated water level at the Kyobashi Station in the castle city for the peak discharge $\left(Q_{p}\right)$ of each flood. The horizontal dotted line (4.5 T.P.m) is the critical water level above which the city would be inundated. The blue line shows the result for the condition before the construction of the Hyakken-gawa Floodway. The red line shows the result for the condition

(a) Discharge in floodway

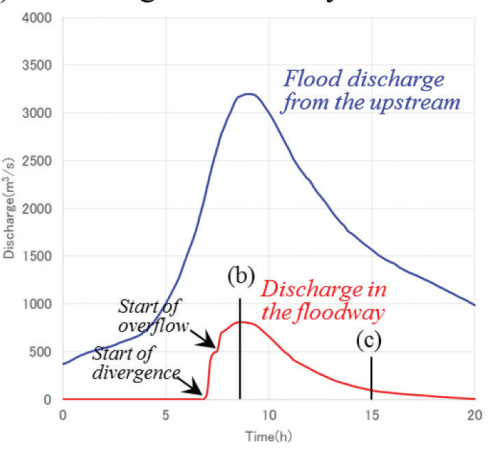

(c) Inundation depth after flood peak

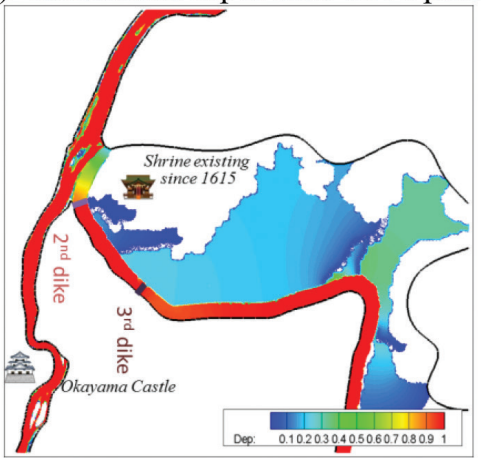

(b) Inundation depth at flood peak

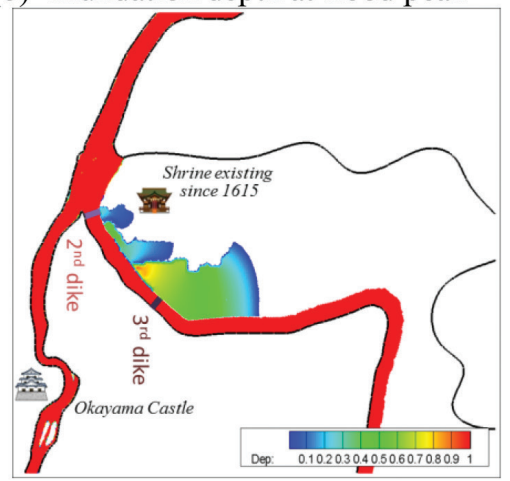

(d) Maximum inundation depth

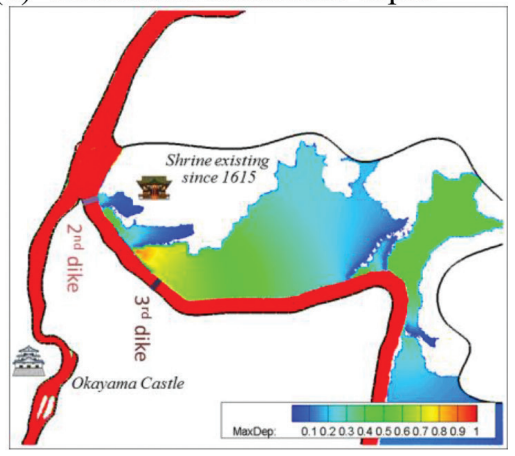

Figure 6: Inundation due to overflow of Hyakken-gawa. 


\section{Flood Risk Management and Response}

in which a part of the flood is diverted to Hyakken-gawa, but bank overflow is not considered in the calculation. The green line shows the case in which the bank overflow is considered.

At $Q_{p}=2,400 \mathrm{~m}^{3} / \mathrm{s}$, the highest water level before the floodway construction was very close to the critical line, and the use of the floodway decreased the water level by approximately $50 \mathrm{~cm}$, which ensured that the city was safe. At $Q_{p}=2,800 \mathrm{~m}^{3} / \mathrm{s}$, the highest water level without the floodway exceeded the critical line, but it fell below the critical line because of the effect of the floodway and further decreased by approximately $50 \mathrm{~cm}$ when bank overflow occurred in the floodway. At $Q_{p}=3,200 \mathrm{~m}^{3} / \mathrm{s}$, the water level exceeded the critical line even with the discharge to the floodway, but it fell below the critical line with the bank overflow in the floodway. At $Q_{p}=3,600 \mathrm{~m}^{3} / \mathrm{s}$, flooding occurred in the castle city, but the volume of inundation (Fig. 7d, color shading) was quite small, and the rate of decrease in the water surface was higher because of the bank overflow in the floodway.

Figure 8 shows the dependence of the highest water level at the Kyobashi Station on the peak discharge from the upstream region $\left(Q_{p}\right)$. The original channel capacity was about 2,400 $\mathrm{m}^{3} / \mathrm{s}$. Flow divergence to the floodway started at $Q_{p} \sim 2,000 \mathrm{~m}^{3} / \mathrm{s}$ when the water level was still $50 \mathrm{~cm}$ below the critical line. The Hyakken-gawa Floodway was effective in preventing inundation in the castle city only when $Q_{p}$ was below $2,800 \mathrm{~m}^{3} / \mathrm{s}$. However, a part of the flow through Hyakken-gawa was released to the east side farmland by bank overflow at $Q_{p} \sim 2,600$ $\mathrm{m}^{3} / \mathrm{s}$ when the water level at the Kyobashi Station was still $50 \mathrm{~cm}$ below the critical line. The overall effectiveness of the floodway including the effectiveness attributed to the effect of the bank overflow continued until $Q_{p}$ was around 3,200 $\mathrm{m}^{3} / \mathrm{s}$. The result suggests that the flood risk reduction was composed of two stages; the flow divergence to the floodway which was

(a) $Q_{p}=2,400 \mathrm{~m}^{3} / \mathrm{s}$

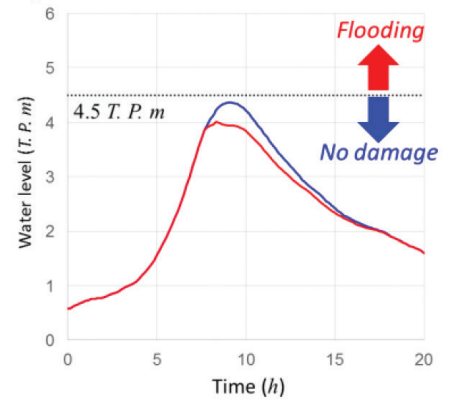

(c) $Q_{p}=3,200 \mathrm{~m}^{3} / \mathrm{s}$

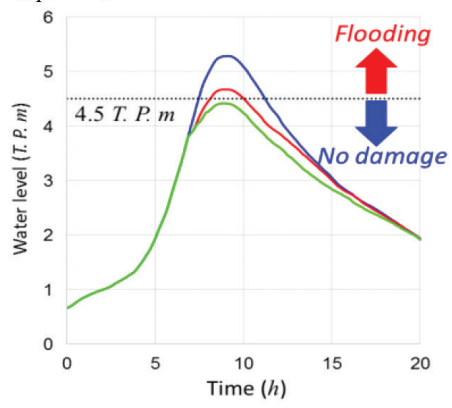

(b) $Q_{p}=2,800 \mathrm{~m}^{3} / \mathrm{s}$

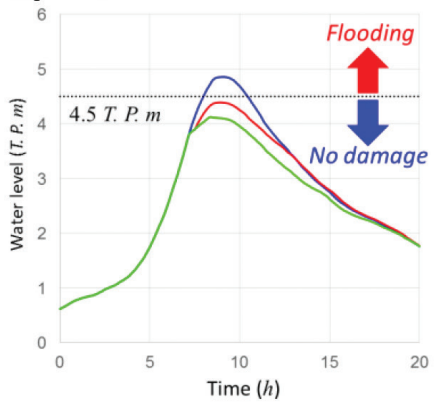

(d) $Q_{p}=3,600 \mathrm{~m}^{3} / \mathrm{s}$

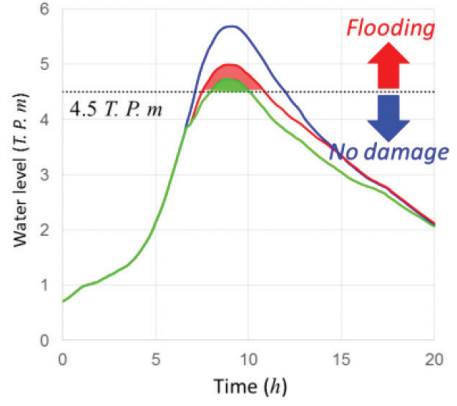

Figure 7: Calculated hydrographs at Kyobashi station. 


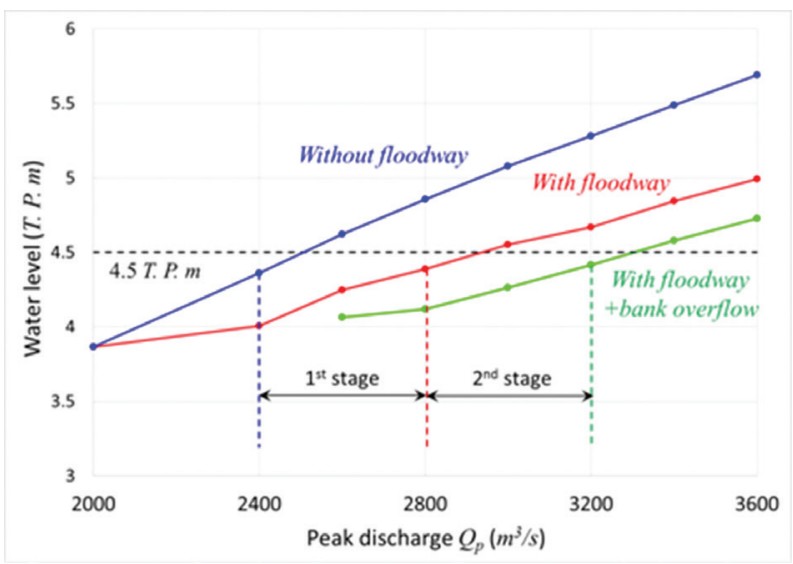

Figure 8: Dependence of highest water level on flood scale at Kyobashi Station.

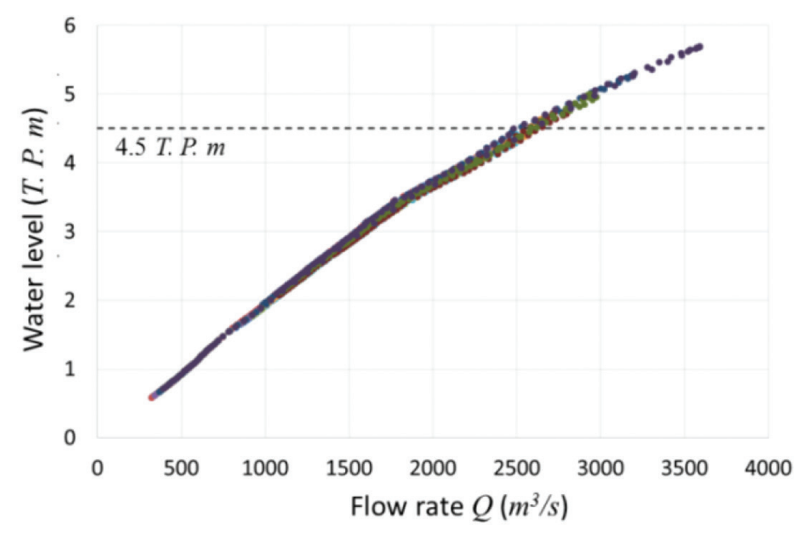

Figure 9: Dependence of water level on flow rate at Kyobashi Station.

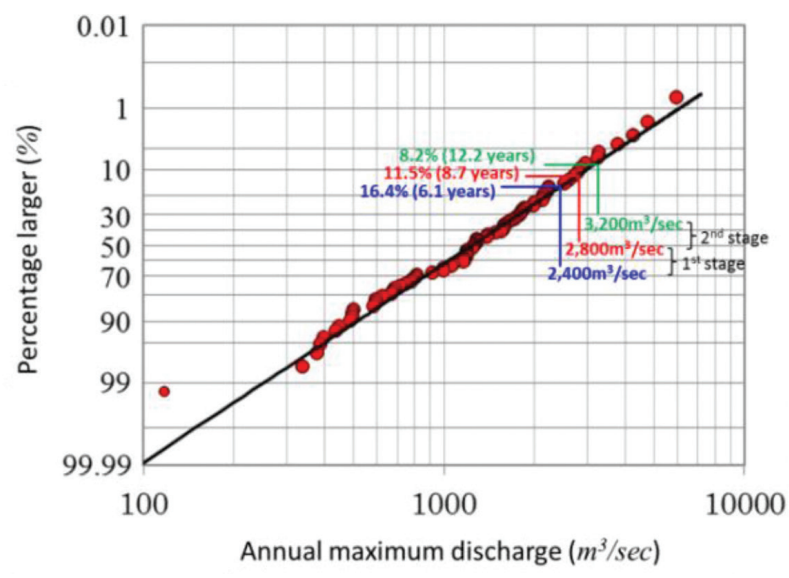

Figure 10: Improvement of safety level. 
effective to $\mathrm{Q}_{\mathrm{p}} \sim 2,800 \mathrm{~m}^{3} / \mathrm{s}$ and the bank overflow to the east side farmland which was effective to $\mathrm{Qp} \sim 3,200 \mathrm{~m}^{3} / \mathrm{s}$.

Figure 9 shows the relationship between the water level and channel discharge recorded at the Kyobashi Station; in this figure, the entire calculation results during all the flood events are plotted together. All the data points approximately lie along a single smooth curve, and the hysteresis due to the unsteady variation in the flow discharge is very weak. This fact suggests that the result described in Fig. 8 will be valid irrespective of the shape of the hydrograph.

The probability plot of the annual maximum discharge in the Asahi River for the last 70 years is shown in Fig. 10 in the form of a Hazen Plot. The data approximately follow the log-normal distribution. Assuming that the probability in the 17th century followed the regression line shown in the figure for the present data, the return period of flooding in the castle city increased from 6.1 to 8.7 years because of the first stage and from 8.7 to 12.2 years because of the second stage.

\section{CONCLUSION}

In this study, the function of the Hyakken-gawa Floodway in reducing the flood risk in Okayama Castle City in the 17th century was investigated by performing a series of numerical flow simulations using a shallow water model. The major conclusions are as follows:

1. The flood risk reduction using the floodway was composed of two stages. The first stage was the flow divergence to the Hyakken-gawa channel, which was induced by the premeditated collapse of the first dike made of earth at the floodway head. The second stage was the inundation of the east side farmland, which was induced by the bank overflow due to the backwater from the third dike. Note that the function of the second dike was to induce a hydraulic jump for flow energy dissipation and to smoothly change the flow direction toward the floodway axis.

2. The first stage of flood control increased the flood discharge safety level of the castle city against inundation from 2,400 to $2,800 \mathrm{~m}^{3} / \mathrm{s}$, which corresponds to an increase in the return period from 6.1 to 8.7 years. The second stage of flood control involving the inundation of the east side farmland further increased the flood discharge safety level to $3,200 \mathrm{~m}^{3} / \mathrm{s}$ and the return period to 12.2 years.

3. The second stage of flood control was realized by suffering the loss of harvest in the farmland roughly once in ten years. Old documents indicate that farmers occasionally petitioned the local government through the regional magistrate, to reinforce the Hyakken-gawa banks, and that the local government gave tax remissions to the 12 farming villages on the east side alluvial plains [1]. These facts suggest that the regional administration gave comprehensive considerations to the farmers and followed suitable procedures while undertaking the transfer of flood risk from the castle city to the farmland through the floodway system.

4. According to the modern policy for flood risk management in Japan, the safety level is kept constant for each river basin, although the land condition changes along the channel. However, recent changes in the global climate might increase the frequency of floods that are larger than the channel capacity under the present regulation for flood risk management. Hence, to reduce the total flood damage on floodplains inundation should be controlled by considering the distribution of land cover and properties on such floodplains. The revaluation of past civil engineering works that used only manual labor would contribute to the creation of a new phase of flood risk management in the near future. 


\section{ACKNOWLEDGEMENTS}

We would like to thank Emeritus Professor Hideo Kikkawa of Tokyo Institute of Technology for his valuable suggestions pertaining to this study. We would also like to thank Editage (www.editage.jp) for providing English language editing. This study was supported by a grant from the RIVER FOUNDATION (Number 27-1212-006).

\section{REFERENCES}

[1] Taniguchi, S. et al.: The history of Hyakken-gawa, Office for construction and administration of Asahi River, Ministry of Construction, 1978.

[2] Imamoto, H., Ishigak, T., Baba, Y. \& Tanaka, N., Experimental study on river improvement for the Asahi River in Edo-era. Historical Studies in Civil Engineering, JSCE, 15, pp. 119-128, 1995. http://dx.doi.org/10.2208/journalhs1990.15.119

[3] Ishikawa, T., Akoh, R., Kikkawa, H. \& Kobayashi, Y., A hydraulic study on the design of Hyakken River Construction in the Edo Period. Journal of Hydraulic Engineering, JSCE ser. B1, 71(4), pp. 613-618, 2015. http://dx.doi.org/10.2208/jscejhe.71.I_613

[4] Zeng, X., Akon, R., Ishikawa, T. \& Nakamura, T., On the efficiency of GPGPU acceleration of Tsunami simulation using an unstructured triangular mesh system. Journal of Hydraulic Engineering, JSCE ser. B1, 69(4), pp. 619-624, 2013. http://dx.doi.org/10.2208/jscejhe.69.I_619

[5] Honma, H., Coefficient of flow volume on low overflow weir. Proceeding of JSCE, 26(6), pp. 635-645, 1940.

[6] Suga, K, Ishikawa, T. \& Kasai, T., Report of hydraulic test on bank collapse by overtopping flow, part of data analysis. PWRI Report, Ministry of Construction, 1760, 1982.

[7] Okayama Office for River Improvement Works: Records of the Past Improvement of Hyakken-gawa, Ministry of Construction, 1983.

[8] Maeno, S., Miyauchi, Y. \& Mori, T., Effect of vegetation on flood flow in the asahi river. Journal of Hydraulic Engineering, JSCE, 48, pp. 757-762, 2004. http://dx.doi.org/10.2208/prohe.48.757

[9] Ishikawa, T., Yoshida, K. \& Minoura, Y., Application of a wuasi-3d numerical model to a flood flow observed in the lower tone river in september. 1998, Journal of Hydraulic Engineering JSCE ser. B1, 69(4), pp. 619-624, 2013. 